\title{
塩 化ビニル樹脂の流動特性
}

森芳郎**

\section{1. 緒言}

合成維維の熔融紡系やプラスチックスの成型加工にお いて，それら材料の流動特性恃，加工の際の温度，成型 機の迴転速度，押出圧力，流量など相関連する操作条件 を決定するるのであって，特に系の直径や成型速度の変 動を防止し品質を均一にするためには，まずこのような 流動特性を明らかにすることが必要である。

本研觉に打いては塩化ビニル樹脂のこのよ5な流動特 性に及に゙す温度および可塑剂配合比の影笠を明らかにす ることを目的として実験を行ったのであるか，一応简単 なレオロジー式がえられたので，その結果をここに報告 する。

\section{2. 解析方法}

Fig.1亿示すような島 㴖製高化式フローテスタ 一を用い， $100 \sim 180^{\circ} \mathrm{C}$ ゆ一定温度で円孔ノズル より試料を押出して圧力 と流量との関係を求め, 流動特性についてモデル を仮定することなく，最 る一般的に $D$ - $\tau$ の対応值 を求めらる, Krieger 法 を応用して解析した。

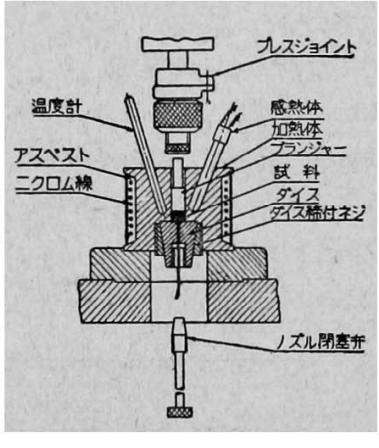

Fig. 1

Flow tester used
'内管流動に和いて，管頪に拈ける新断応力を $\tau_{m}=$ $p R / 2 l$, 見挂流動度を $\phi_{a}=8 l Q / \pi R^{4} p$ とすれば，速度勾 配は，

$$
D=\tau_{m}\left(\phi_{a}+\frac{1}{4} \frac{d \phi_{a}}{d \ln \tau_{m}}\right)
$$

と表わされる (Krieger の式)。 试は $\frac{1}{\phi_{a}} \frac{d \phi_{a}}{d \ln \tau_{m}}=\frac{d \ln \phi_{a}}{d \ln \tau_{m}}=\frac{d \ln Q}{d \ln p}-1$ の関保を 用いてつぎように書き代えられる。

$$
D=\frac{Q}{\pi R^{3}}\left(3+\frac{d \ln Q}{d \ln p}\right)
$$

したがって $p$-Q関倸の実駼結果を，両対数上下点緅す れ朔, その曲線上の任意の $p$ 対応するQおよび曲線の

*昭和 32 年 12 月 28 日受理

* 束京大学工学部化学工学筑室
勾配 $d \ln Q / d \ln p$ から（2）の右边を計算し，D-pすな わち $D-\tau$ の対応関係を求めることができる。

\section{3. 実験結果}

PVC 樹脂は呉羽化成，新日本窒素，日本ゼオン，モン サント化成 4 社のるのを使用し，重量比でそれらの粉末

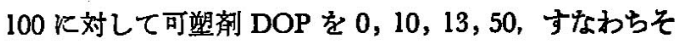
れとれ $C=0,9.1 ， 23 ， 33 \%$ の 4 種，それ《安定郕 DBL を和のおの 5 の割合て加え, 卓上カレンダで充分に捏和 して試料を準備した。このような試料䄪 $3 \mathrm{gr}$ を Fig. 1 のシリンダ内に入れ, 所定の温度に加熱し, 孔径 $2 R=$ $1.0 \mathrm{~mm}$, 長さ $l_{1}=20 \mathrm{~mm}$ の No. 1 /ズルおよび $2 R=$ $1.0 \mathrm{~mm}, l_{2}=28.1 \mathrm{~mm}$ の No. 2 ノズルの 2 個を使用し て押出し，両対数秘上に 2 本の $p-Q$ 曲線を求めた。こ れらの曲線は一般にほほ平行に弯曲している。ノスルの 入口および出口附近における末端の影響を除くために， このような 2 本の曲線の同一流量Q飞対疬する圧力 $p_{1}$ および $p_{2}$ の差 $p=p_{2}-p_{1}$ とQの関係を求めれば，これ はほぼ末端の影瑤のない $l=l_{2}-l_{1}=8.1 \mathrm{~mm}$ の長さの， ズルKついての特性と見做される。このような $p$ - $Q$ 関 係を求める実験を，前述の各試料炕いて，温度を 100 , $120,140,160,180^{\circ} \mathrm{C}$ の 5 度変えて行った。それらの 結果はいずれの場合す両対数紙上で直線でよく表わすこ とができ，たとえば日本ゼオンのあのについては Fig. 2 に示寸ことくである。したがっていま

$$
Q=\alpha p^{n}
$$

と括けば（2）は

$$
D=\alpha p^{n}(3+n) / \pi R^{3}
$$

となりこれに $\tau_{m}=p R / 2 l$ の関係を代入すれば

$$
D=\alpha(3+n)(2 l){ }^{n} \tau_{m} n / \pi R^{3+\pi}
$$

と表わされる。この式において $D$ と袢は管壁における 值であるが、これらは材料内部の任意の点に拊ける $D$ と ての関係を表わすと考皇てるよから，この場合は通常 の $\tau^{n}$ の形のレオロジー式

$$
D=\tau^{n / \eta}
$$

が成立すると考光られる。たビしここで

$$
\eta=\pi R^{3+n} / \alpha(3+n)(2 l)^{n}
$$

$n$ の值は Fig. 2 の直線の勾配から決まる。可塑剤配 合比および温度を变えて実験した結果は，本実験の範囲 


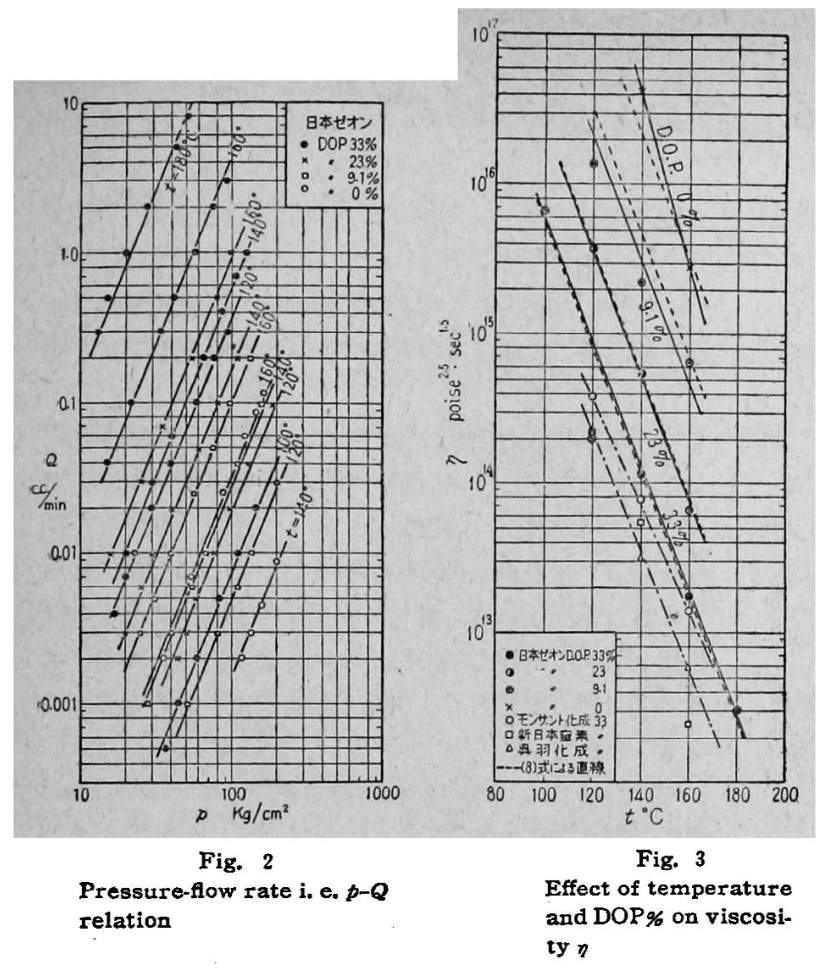

となった。Fig. 3 中の点線の直線はそれぞれ $C=0,9.1 ， 23 ， 33 \%$ 場合の $\eta$ の値を (8) 式によって求めた例を示す。また同図に呉 羽，新日本窒素，モンサント化成各 $33 \%$ の場 合の実験結果す示したが，日本ゼオンの場合 とほは同様の㑯向にあることがわかる。

\section{4. 結 論}

塩化ビニル樹脂の流動特性は本实驗の䈌囲 では $D=\tau^{n} / \eta$ でよく表わされ，日本ゼオン のものについてはほぼ $n=2.5, \lg _{10} \eta=22.3$. $-(4.25 t+(6.91 c) / 100$ で表わすことができ る。また呉羽，新日本窒素，モンサント化成 のものもほぼ同様の傾向を示す。

附記：本研究は文部省化学促進研究費に上 って行ったすのであり，実験と計算は井上猛 司, 滝口幸夫両君の協力によるるのであるこ とを附記し感謝の意を表する。

\section{Nomenclature}

$\alpha:$ coefficient of flow rate $\quad[-]$

$C$ : weight $\%$ of plasticizer DOP to PVC

$D$ : velocity gradient

$[1 / \mathrm{sec}]$

$l, R$ : length and radius of nozzle [cm]

$n$ : index number of $D-\tau$ relation $\quad[-]$

$p:$ pressure $\quad\left[\mathrm{kg} / \mathrm{cm}^{2}\right]$

$Q:$ rate of flow through a nozzle [cc/ $\mathrm{min}]$

$t:$ temperature

$\tau, \tau_{m}:$ shearing stress, general and on the wall of nozzle

$\left[\mathrm{kg} / \mathrm{cm}^{2}\right]$ について DOP 配合比をパラメータにして片対数紙上に 示せば Fig. 3 のことくであり，これらる実線で示した ことく，ほぼ平行な直線で表わすことができる。さらに 温度を一定にして $\lg _{10} \eta-C$ 関係を画けば,これるほぼ直 線で表わすことができた。以上の諸線図から $n-t-C$ 関 係を求めた結果は

$\lg _{10} \eta=22.3-(4.25 \mathrm{t}+6.91 C) / 100$

$\eta$ : viscosity

$\phi_{a}:$ apparent fluidity $=8 l Q / \pi R^{4} p$

\section{Literature cited}

1) Krieger, I. M. : J. Appl. Phys., 28, 147 (1952)

2) Mori, Y.: Chem. Eng. Japan., 19, 170 (1955)

\section{Effect of Temp. and DOP \% on Rheological Property of Polyvinyl Chloride}

Yoshiro Mori*

Summary : In the range of this experimental study, rheological equation of polyvinylchloride is quite exactly written as $D=\tau n / \eta$. And $n$ and $\eta$ are approximately reprsented as follows,

$$
n=2.5, \quad \lg _{10} \eta=22.3-(4.25 t+6.91 c) / 100 \text {. }
$$

- Faculty of Engineering, University of Tokyo 